\title{
Piezoelectric Immunosensor for the Determination of C- Reactive Protein
}

\author{
Miroslav Pohanka \\ Faculty of Military Health Sciences, University of Defence, Trebesska 1575, CZ-500 01 Hradec \\ Kralove, Czech Republic \\ E-mail: miroslav.pohanka@gmail.com
}

doi: $10.20964 / 2019.09 .02$

Received: 7 May 2019 / Accepted: 2 June 2019 / Published: 31 July 2019

\begin{abstract}
C-reactive protein (CRP) is a common biomarker of inflammatory processes and it typically serves for the distinguishing of bacterial and viral diseases. It is typically measured in the blood, plasma or serum by immunoassay like agglutination or enzymatic immunoassays. In this paper, a new immunoassay based on a piezoelectric biosensor was introduced. QCM with basic frequency of oscillations $10 \mathrm{MHz}$ and gold electrodes served as a platform and it was modified with antibodies against CRP and silica nanoparticles. Separately, antibody functionalized silica nanoparticles were prepared and they further served for signal amplification. CRP was assayed with limit of detection equal to $0.080 \mathrm{mg} / \mathrm{l}$. The assay was successfully validated to standard ELISA method and no significant interference by IgM, TNF $\alpha$ and albumin was observed. The biosensor-based assay appears to be practically applicable and can serve for routine diagnosis purpose.
\end{abstract}

Keywords: affinity; antibody; biosensor; CRP; C-reactive protein; immunosensor; infection; inflammation; label free assay; liver; piezoelectric; quartz crystal microbalance

\section{$\underline{\text { FULL TEXT }}$}

(C) 2019 The Authors. Published by ESG (www.electrochemsci.org). This article is an open access article distributed under the terms and conditions of the Creative Commons Attribution license (http://creativecommons.org/licenses/by/4.0/). 